\title{
Exploration and Reflection on the Library Emergency Services of Colleges and Universities under COVID-19 -An Investigation on Anti-Epidemic Service in Hubei Colleges and Universities Library
}

\author{
Lang Chen ${ }^{1}$ and Chi Zhang ${ }^{1, *}$ \\ ${ }^{1}$ Huazhong University of Science and Technology Library, Wuhan, 430074, China \\ *Corresponding author. Email: 5788484@qq.com
}

\begin{abstract}
In the course of novel coronavirus pneumonia (COVID-19) epidemic, the library service guarantee measures in colleges and universities were summarized and analyzed by investigating the official websites and WeChat public accounts of 32 public colleges and universities in Hubei Province. This work reflected on colleges and universities library service work in the special period of epidemic from three aspects and tried to put forward reasonable suggestions. It is expected to offer references and thinking for colleges and universities library emergency services when facing major public health emergencies.
\end{abstract}

Keywords: Novel coronavirus pneumonia; Colleges and universities library; Service; Research; Electronic

resources

\section{INTRODUCTION}

From the end of 2019 to the beginning of 2020, the outbreak of COVID-19 was concentrated in Wuhan and spread rapidly across the country. This is a serious infectious disease which broke out again after SARS in 2003. The epidemic virus is coming fiercely, spreading rapidly, treating difficultly, preventing and controlling difficultly, involving a wide range and having a far-reaching influence, which can be described as unprecedented. The outbreak of the novel coronavirus epidemic is a major test for China's public health system, which has greatly tested the country's ability to cope with major public emergencies. Although librarians can't fight like medical workers in the front line of anti-epidemic, they can show their responsibilities by exporting better services to readers after the outbreak of the epidemic. The Library Society of China, in conjunction with various libraries and digital resource providers, pushes various types of learning resources to readers free of charge through the "reading consortium - digital sharing reading service platform", which has been widely concerned by the library community [1]. Hubei university library committee and Hubei library association initiated and organized libraries to donate books and periodicals for shelter hospitals. In the special period of epidemic, the library should take "reading" to attack "poison", thus helping patients and isolators relieve their tension and maintain a good mental state. In the middle and late February, the libraries of Wuhan University, Huazhong University of Science and Technology, Hubei University, etc., responded positively under the unified and coordinated organization of provincial working committee. They quickly organized forces to donate more than 10000 copies of literature, art and other leisure books to the shelter hospitals and isolation points in Wuchang District and Qiaokou District, and offered free electronic books, audio books and other online reading resources. Also, they offer spiritual food for COVID-19 patients and greatly encourage patients' morale. As a public place to obtain information resources, the library is characterized by dense books and periodicals and relatively centralized personnel. Once the outbreak is concentrated, it will bring greater social impact. Therefore, the library emergency management should be done well. The occurrence of special events also brings great challenges to library and information service and management. What kind of emergency response mechanism and emergency service and management ability should be established? Can the library's technical support, service efficiency and document resources guarantee meet the needs of readers? Can the core business of the library be carried out orderly under the special background? In the fight without smoke and virus, the library and all sectors of society work together, with their own practical action to the reader to submit a satisfactory answer.

Based on the author's investigation, 32 public colleges and universities library in the province published 872 tweets through the library's WeChat public number from January 23rd to April 7th, averaging 11.5 tweets each day and 20.8 tweets each library. WeChat has become the mainstream online service and publicity method for colleges and university libraries during the novel coronavirus epidemic. Under the guidance of "closing and not closing" idea, a series of resource services and cultural promotion activities 
have been carried out in the way of home office and online service.

In the course of COVID-19 epidemic, 32 public colleges and universities in Hubei Province were selected to carry out investigation and research on their service status by using WeChat public accounts and network platforms. Also, this work analyzed the shortcomings of library services during the current epidemic situation, and tried to put forward a series of improvement suggestions. It is expected to improve the service capacity of library in facing major public health emergencies.

\section{SERVICE STATUS OF COLLEGES AND UNIVERSITIES LIBRARY IN THE PROVINCE DURING THE OUTBREAK}

\subsection{Carrying out a joint prevention and control mechanism internally and externally}

The COVID-19 epidemic is fierce, and prevention and control become the priority among priorities. The librarian is the front-end of the whole group prevention and control fortress. Only when the basic librarian is firmly prevented can the epidemic prevention work of the library be a complete victory. Many college and university libraries in the province have constructed a joint defense system of "curator in charge, department director and basic level librarian", so that the prevention and control work can be carried out orderly and efficiently. At the same time, the QQ group and WeChat group from the curator to the librarian of each department and office were established, and the grid information collection and release platform was established to ensure the smoothness of the upper level information. It is necessary to remind and urge each librarian to report the body temperature on time. Also, it should grasp the health status and ideological trend of the librarians during the anti-epidemic period in the closed house, thus preventing the librarians from anxiety. Based on the requirements of epidemic prevention, special personnel should be organized every day to strengthen the sanitation and disinfection of public space and reading seats on each floor in the museum, thereby ensuring the clean and safe environment.

After the outbreak of the epidemic, the leaders from Hubei university library committee attached great importance to it, and immediately established the anti-epidemic support WeChat group. They dredged the channels of counterpart support, and established the counterpart support mechanism. College and university libraries in the province worked hand in hand to prevent and take measures against the masses. The committee calls on all kinds of university libraries in Hubei Province to fully consider information needs between different reader groups, timely adjust the service mode, actively do a good job of joint prevention and control and online service for readers, thus arousing the social responsibility of librarians.
In late February, Wuhan University of Technology launched the formulation of the implementation plan for opening the library. Through many remote meetings to discuss the details of the plan, and the content of the plan was revised for many times. Finally, a 268 page implementation plan for opening the library in the late stage of the epidemic was formulated.

The outbreak of novel coronavirus epidemic is sudden, fierce and lasting for a long time, leading to the shortage of emergency supplies such as masks, protective clothing, disinfectant, etc. University libraries raise epidemic prevention materials through various channels. Wuhan University and Huazhong University of Science and Technology raised masks, disinfectants and other materials through donations from alumni and other fraternities. On February 12, Three Gorges University received 500 kg pasteurization solution donated by Hubei Huixun Technology Co., Ltd.

\subsection{The library was closed and postponed urgently and a green channel for borrowing books was opened}

Located in the epidemic area of the storm center, Wuhan University Library and Huazhong University of Science and Technology Library, two "double first-class" university libraries in Wuhan, Hubei Province, took the lead in issuing the temporary closure notice on January 23, 2020. On January 28, 2020, the Huazhong University of Science and Technology library continued to issue a notice on the opening extension of the library according to "the notice of Huazhong University of Science and Technology on delaying the opening time in 2020". In order to alleviate the inconvenience brought to teachers and students by the delayed opening, many university libraries will exempt readers from the penalty if they delay borrowing or return books on time due to the delay, thus opening a green channel for the traditional borrowing business of the library. This measure can effectively avoid the spread of epidemic situation caused by crowd gathering, reduce the cross infection between teachers and students caused by crowd gathering, and protect the health and life safety of readers and staff. Also, it can ensure that teachers and students can borrow and return books smoothly after school, thereby avoiding the worries of teachers and students.

\subsection{Opening a green channel for off-campus remote access in virtue of technology}

Electronic resources have become the main way for readers to obtain resources with the advantages of large quantity, rich types, fast updating speed, wide spread, etc. According to the Ministry of Education "school from class, closed not suspended" guidance, colleges and universities in the province actively adopt the online teaching mode. During the winter vacation, many teachers and students 
also use the holiday to do scientific research, write papers, apply for funds, etc. Due to the superposition of comprehensive factors, teachers and students' demand for electronic resources is more urgent. It is necessary to ensure a 24-hour open mode every day to maximize the benefits of teachers and students teaching, learning, research work escort.

Through the network survey, the author selected the WeChat official account, website's tweets and news bulletins of 32 public colleges and universities library in the province from January 23, 2020 to April 7, 2020, and made statistics on the protection of the electronic resources.

Currently, the main way for college and university library at home and abroad to access electronic resources is virtual private network (VPN). On the other hand, it includes Shibboleth authentication, CARSI authentication, library electronic resource access system, remote access, temporary account, short-term off campus roaming and MYLOFT [2]. CARSI is a unified authentication and resource sharing infrastructure built initially by Peking
University Computing Center based on Shibboleth and oriented to CERNET. Through this service, teachers and students can use the unified school identity authentication account directly to log in and access the docking resources on multiple platforms without any limitation in time, place, terminal or networking form. All the functions of resources can be realized through the web page only. CARSI not only offers a better way to access resources outside school, but also expands the platform and mobile resource application scenarios. Before the outbreak of the epidemic, none of the 31 provincial public universities except Wuhan University had joined the organization, and the proportion of those who had joined the organization was not high. However, 19 public college and university libraries have joined in, accounting for $59.3 \%$ after the outbreak of the epidemic (statistics time as of April 7). Among them, 14 colleges and universities have officially launched CARSI access channels, and the proportion of data will be higher as time goes on. Table 1 makes statistics on whether the 32 public colleges and universities library in Hubei Province has added CARSI access mode and the upper limit time.

Table 1. Overview on off-campus remote access to electronic resources of public colleges and universities library in the province

\begin{tabular}{|c|c|c|c|c|}
\hline $\begin{array}{l}\text { College and university } \\
\text { name }\end{array}$ & Off-campus access system & $\begin{array}{l}\text { Number of } \\
\text { off-campus visits }\end{array}$ & $\begin{array}{l}\text { Whether to Add } \\
\text { CARSI access } \\
\end{array}$ & Online time \\
\hline Wuhan University & $\begin{array}{l}\text { VPN, setting up the proxy server } \\
\text { and CARSI }\end{array}$ & 3 & Yes & 2019-11-11 \\
\hline $\begin{array}{l}\text { Huazhong University of } \\
\text { Science and Technology }\end{array}$ & VPN and CARSI & 2 & Yes & 2020-02-01 \\
\hline $\begin{array}{l}\text { Wuhan University of Science } \\
\text { and Technology }\end{array}$ & dr2am & 1 & Be debugging & 2020-02-15 \\
\hline Yangtze University & IFC IRAS & 1 & & \\
\hline $\begin{array}{l}\text { Wuhan Institute of } \\
\text { Technology }\end{array}$ & VPN and CARSI & 2 & Yes & 2020-03-03 \\
\hline $\begin{array}{l}\text { China University of } \\
\text { Geosciences (Wuhan) }\end{array}$ & VPN, IFC IRAS and CARSI & 3 & Yes & 2020-03-10 \\
\hline Wuhan Textile University & VPN and CARSI & 2 & Yes & 2020-02-04 \\
\hline $\begin{array}{l}\text { Wuhan Polytechnic } \\
\text { University }\end{array}$ & IFC IRAS & 1 & & \\
\hline $\begin{array}{l}\text { Wuhan University of } \\
\text { Technology }\end{array}$ & VPN and CARSI & 2 & Yes & 2020-02-20 \\
\hline $\begin{array}{l}\text { Hubei University Of } \\
\text { Technology }\end{array}$ & IFC IRAS and CARSI & 2 & Yes & 2020-03-27 \\
\hline $\begin{array}{l}\text { Huazhong Agricultural } \\
\text { University }\end{array}$ & VPN, IFC IRAS and CARSI & 3 & Yes & 2020-02-16 \\
\hline $\begin{array}{l}\text { Hubei University of Chinese } \\
\text { Medicine }\end{array}$ & IFC IRAS & 1 & & \\
\hline $\begin{array}{l}\text { Central China Normal } \\
\text { University }\end{array}$ & VPN & 1 & & \\
\hline Hubei University & VPN & 1 & Be debugging & \\
\hline Hubei Normal University & $\begin{array}{l}\text { Remote access aystem and } \\
\text { CARSI }\end{array}$ & 2 & Yes & 2020-03-13 \\
\hline $\begin{array}{l}\text { Huanggang Normal } \\
\text { University }\end{array}$ & VPN & 1 & & \\
\hline Hubei Minzu University & $\begin{array}{l}\text { Off-campus access system based } \\
\text { on Shibboleth, IFCIRAS and } \\
\text { Huiwen }\end{array}$ & 3 & & \\
\hline Hanjiang Normal University & No off-campus access & 0 & & \\
\hline $\begin{array}{l}\text { Hubei University of Arts and } \\
\text { Science }\end{array}$ & No off-campus access & 0 & Be debugging & \\
\hline
\end{tabular}




\begin{tabular}{|c|c|c|c|c|}
\hline $\begin{array}{l}\text { Zhongnan University of } \\
\text { Economics and Law }\end{array}$ & VPN, IFC IRAS and CARSI & 3 & Yes & 2020-02-18 \\
\hline $\begin{array}{l}\text { Wuhan Institute of Physical } \\
\text { Education }\end{array}$ & VPN & 1 & Be debugging & 2020-03-12 \\
\hline $\begin{array}{l}\text { South-central University For } \\
\text { Nationalities }\end{array}$ & VPN and CARSI & 2 & Yes & $2020-02-13$ \\
\hline $\begin{array}{l}\text { Hubei University of } \\
\text { Automotive Technology }\end{array}$ & IFC IRAS and CARSI & 2 & Yes & 2020-03-22 \\
\hline $\begin{array}{l}\text { Hubei Engineering } \\
\text { University }\end{array}$ & IFC IRAS & 1 & & \\
\hline $\begin{array}{l}\text { Hubei Polytechnic } \\
\text { University }\end{array}$ & IFC IRAS & 1 & & \\
\hline $\begin{array}{l}\text { Hubei University of Science } \\
\text { and Technology }\end{array}$ & VPN & 1 & & \\
\hline $\begin{array}{l}\text { Hubei University of } \\
\text { Medicine }\end{array}$ & IFC IRAS & 1 & & \\
\hline Jianghan University & IFC IRAS & 1 & & \\
\hline $\begin{array}{l}\text { China Three Gorges } \\
\text { University }\end{array}$ & Digital portal system & 1 & & \\
\hline $\begin{array}{l}\text { Hubei University of } \\
\text { Economics }\end{array}$ & VPN and CARSI & 2 & Yes & $2020-02-16$ \\
\hline $\begin{array}{l}\text { Hubei University Of } \\
\text { Education }\end{array}$ & CARSI & 1 & Yes & 2020-03-22 \\
\hline Wuhan Business University & VPN & 1 & Be debugging & \\
\hline
\end{tabular}

It can be seen from Table 1 that 14 universities support two or more remote access modes among the 32 public universities surveyed, accounting for $43.8 \%$. Among them, Wuhan University, China University of Geosciences (Wuhan), Huazhong Agricultural University, Zhongnan University of Economics and Law and Hubei Minzu University support the third access mode, accounting for $15.6 \%$. This ensures the diversity of access channels covers more users and brings convenience for readers.

Based on the author's understanding, there are also private undergraduate colleges aside from the survey universities listed in the table, such as Wuchang Shouyi College, and provincial vocational colleges such as Wuhan Polytechnic and Wuhan City Vocational College that have opened the CARSI remote access mode. This can effectively meet the needs of users and implement the purpose of "serving readers" incisively and vividly.

\subsection{A series of online themed activities}

In order to actively respond to the slogan of staying at home and enrich the cultural life of teachers and students, colleges and universities library has carried out a series of theme activities. The Wuhan University library has officially launched the special topic of "online teaching and research at home". It especially plans to launch the collection activities of "reporting peace by your message" and "come on Wuhan, come on little cloth" to disperse the severe cold of the epidemic with the warmth of books. The Central China Normal University library has launched a 21-day reading and punching activity called "reading together through windows in Wuhan". Students from colleges and universities in Hubei Province are invited to participate in this activity, thus learning about Wuhan from ancient and modern literati in an all-round way, and to refuel Wuhan and China in their own way. The Wuhan Institute of Technology library leads teachers and students to carry out the "one person, one book and one month" winter holiday reading and clock in activity to read together in this special winter. Huazhong Agricultural University calls on teachers and students to carry out a series of "Shishan reading festival" to encourage students to actively participate. The Library Society of China and
Wuhan University library jointly held the second "library cup" theme image creative design collection activity. Beijing Zhilian Qidian Information Technology Co., Ltd. and Hubei University library jointly held an online activity of "prize-winning answers to epidemic prevention knowledge in battle classes" for all teachers and students in Hubei provincial colleges and universities. It encouraged teachers and students to strengthen their self-prevention awareness and improve their protection ability, thereby preparing for the first class ready. Hubei Provincial Library Work Committee has hosted the "life, war epidemic" university book review and film review competition, and 32 college and university libraries in the province have responded positively.

\subsection{Orderly carrying out the service work such as checking and quoting, science and technology novelty retrieval and document delivery}

In the course of epidemic prevention and control, the library will not stop its work when it is closed, and will continue to offer literature resources, academic services and intellectual property information services to ensure the needs of all teachers and students. Facing the needs of teachers and students to carry out teaching and scientific research, the Librarians of Huazhong University of Science and Technology library carry out remote online office, actively carry out scientific and technological novelty retrieval, paper retrieval and intellectual property information services. Through the newly launched "science and technology novelty retrieval and information service management system" of the library during the epidemic period, it accepted various science and technology novelty retrieval projects and paper retrieval work. Relying on this management system, the whole process is online from accepting commission, communication to report completion and delivery. The staff work at home and finish the report remotely. With the approval of the library leaders, the staffs on duty are allowed to enter the library to print the report and affix the seal. Finally, the scanned copy of the report is sent to the client by e-mail, thus 
realizing zero contact in the whole process. In order to meet the needs of teachers and students for humanities and social sciences literature, CASHL (Chinese university humanities and social sciences literature center) from Huazhong University of Science and Technology and Huazhong Agricultural University will be free of charge until the end of the epidemic from February 20, 2020.

\subsection{Persisting in carrying out information literacy education for online readers}

Through the QQ group, WeChat official account, mobile library, network information platform, etc., the colleges and universities library ensure that readers can get in touch with librarians smoothly, and the readers' consultation and needs are timely responded. The subject librarian of Huazhong University of Science and Technology offers targeted scientific research and teaching support for teachers and students, including multi-dimensional one-stop services such as ensuring literature resources, service collection and citation, improving information literacy, etc. Wuhan University library has set up an information literacy channel on its WeChat public account for the period of the epidemic, and carried out online teaching and live answering questions through the "super star learning channel". Aiming at the modules of information literacy education in colleges and universities, the Wuhan University of Technology library carried out a series of university information literacy courses by using micro courses during the closing period [3]. It includes five series of contents: theory, system, academic writing, knowledge management, application scenarios, etc. University libraries in the province also collect various teaching platforms to teach online teaching skills to teachers who become "anchors", and recommend them to carry out online teaching through courses of love, rain classroom, wisdom tree network, super star Erya network general education platform, etc.

\section{ANALYSIS ON COLLEGES AND UNIVERSITIES LIBRARY SERVICES UNDER COVID-19}

\subsection{Strengthening service consciousness}

Accordingly, there are still some universities and colleges in the province whose library information service work is at a standstill or only maintains routine information service work in the course of COVID-19 epidemic. The emergency service capacity in facing major public security incidents needs to be improved. Based on the author's investigation, 1 university library in 32 public colleges and universities have not opened WeChat official account, and 3 university libraries have never updated the content of WeChat official account. From January 23rd to April 7th, the WeChat official account from 4 colleges and universities released a single digit in a period of more than two months.

On February 4, the Ministry of Education issued the "guiding opinions on the organization and management of online teaching in colleges and universities during the period of epidemic prevention and control". It requires schools to actively carry out online teaching activities such as online teaching and online learning, and the demand for electronic teaching materials is booming [4]. According to the tweets published by 32 university libraries, Wuhan University and Wuhan University of Technology libraries have undertaken the arduous task of offering resources for online teaching. Wuhan University of Science and Technology introduced librarians to open the "5 +2 " working mode and the "world salvage" electronic teaching material. It obtained electronic textbooks for 2,297 courses and produced 693 pages of electronic textbook guides, and undergraduate course guarantee rate reached $82 \%$. The majority university libraries have not published the related work of compiling electronic textbooks. It can be seen that the emergency response speed of library in facing public emergencies needs to be improved, and the demand focus of information resources should be clearer, thereby achieving a targeted goal.

For more than two months, most cities in Hubei Province have remained under "lockdown" or strict control over the epidemic. In the teaching and scientific research process, teachers and students need vast information resources as support. Librarians should continue to adhere to the "white + black" working mode, provide efficient and high-quality services as soon as teachers and students need, offer guidance and direction for their teaching, learning and research work, and reflect the responsibilities and actions of a librarian during the epidemic test.

\subsection{Actively carrying out in-depth cooperation with database vendors to expand digital resources}

Since the outbreak of the epidemic, the whole country has made concerted efforts to overcome the difficulties and contribute their own strength to win the epidemic war. Many database companies, publishers and Internet enterprises at home and abroad have constantly upgraded their services and launched a series of measures to facilitate the readers. For example, CNKI, Wanfang Data, superstar academic resources and Edison online lecture hall are open to the public for free. Many information service companies specially set up online training services to meet the learning needs of readers, such as "web of science online lecture" held by Clarivate for scientific researchers, "Kehui Sci-Fund platform" launched by Wanfang for free, and superstar fine elegance paper testing system is open to readers for free. However, the free access to various types of database information is scattered, complex and various ways of entrance. In order to facilitate readers, 17 university libraries in Wuhan University, Huazhong University of Science and 
Technology, Wuhan University of Technology, Huazhong Agricultural University and other universities have collected and screened the commonly used free resources information. The official account is posted on the campus network and WeChat public number platform for readers' reference.

As one of the most important components of library resources, digital resources have become the first choice for teachers and students to obtain information resources under COVID-19. After all, the number of electronic literature resources is still limited, and many high-quality databases are not open to readers for free, which hinders the progress of readers' teaching, learning and research to a certain extent. Moreover, many of the above-mentioned free literature resources are only free for a limited time. Once the epidemic is over, readers will no longer have access to the resources they need. Accordingly, the library can explore a more economical and long-term way to help readers access electronic literature resources. It is possible to try to establish a model for integrating copyright interests with publishers [5]. For example, the digital distribution mode of "rent before buy" is put forward (i.e., the library only needs to prepay the rent of the right to use some electronic resources, and it can purchase electronic literature resources according to the needs of users). It can greatly reduce the cost of purchasing electronic resources and the blindness of database purchase. At the same time, open access to resources is advocated, and users can get paid digital resources on demand.

\subsection{Analysis on colleges and universities library services under covid-19}

In the course of epidemic, the non-contact and low-risk online service mode became the main form of library service in the special period under the call of "cloud coronavirus epidemic prevention". Services such as collection and citation, science and technology novelty retrieval, document delivery, intellectual property information service, duplicate paper search, reference service, etc., can be entrusted through online network platform. The librarians who work at home can communicate with users remotely and feedback the processing results. For example, Wuhan University, Huazhong University of Science and Technology and Wuhan University of Technology provide official account of information consultancy service and relevant contact methods through library's official website and public number, including work QQ and contact telephone. The service work responsibility should be assigned to people. During the delay period, more "contactless" online reading activities, online theme collection activities, anti-epidemic knowledge competition columns, etc., can be recommended to attract teachers and students to participate in them. In order to enrich family life against epidemic, it should popularize COVID-19 knowledge to teachers and students, thereby preventing and controlling novel coronavirus in a scientific way and spread positive energy.

\section{CONCLUSION}

The outbreak of COVID-19 is a severe test to all mankind. When facing this disaster, librarians are optimistic and turn the crisis into a turning point. They try their best to use new technology and new ideas to open up various new ways to serve readers, strive to explore online service mode, achieve resource integration and sharing, and support teachers and students' teaching and scientific research work in a multi-pronged way. By combing and summarizing the library service situation of colleges and universities in Hubei Province during epidemic prevention, we realize that college and university libraries have limited practical experience in emergency service when facing major public health emergencies. Also, we need to further improve our management ability to cope with new opportunities and challenges. Although there is a long way to offer high-quality services, librarians will continue to work with readers to improve the level and connotation of services, thus better-serving teaching and scientific research.

\section{REFERENCES}

[1] The Library Society of China. In the Course of Anti-epidemic, Boosting Online Learning Efforts Again - The Library Society of China Pushes Free Resources through the "Reading Consortium Platform" [EB/OL]. [2020-02-19].http://www.lsc.org.cn/contents/1342/1477 $0 . \mathrm{html}$.

[2] Tan Huan. Exploration and Analysis on Resource Service in the Double First-class College and University Libraries during the Anti-epidemic Period [J]. College and University Library Work, 2020, 40(3): 52-56.

[3] Huang Ruhua, Huang Yuting. Discrimination Screening for Major Public Health Emergencies Discussion on the Importance of Public Information Literacy Education from the Prevention and Control of the COVID-19 Epidemic [J]. Library, Information and Knowledge, 2020(2): 9-12.

[4] Ministry of Education. Guiding Opinions on the Ministry of Education's Leading Group for Response to the COVID-19 Epidemic on the Organization and Management of Online Teaching in Regular Colleges and Universities during the Epidemic Prevention and Control Period [EB/OL]. [2020-03-18]. http://www.cac.gov.cn/2020-02/05/c_15824432288620 58.html.

[5] Yang Hua, Du Zhiping. Symbiosis and Cooperation between Digital Publishers and Libraries: Interest Gaming, Cross-border Thinking and Governance Approaches [J]. Publishing Wide Angle, 2019, (9): 33-35, 93. 